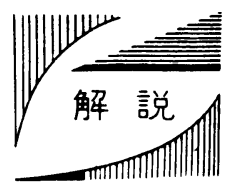

\title{
ねじり振動に関する最近の技術動 向*
}

\section{1. まえがき}

船舶用ディーゼル機関のねじり振動については，古く から数多くの研究が行われており, 理論的には解明され つくされた感があるが，それにあかかわらず，実船にお いてねじり振動に起因する事故がかならずしあ皆無には なっていない。これは技術の進歩に伴ってより強い要望 がユーザ側からでていること屯影響している．例えば従 来ならば主危険速度附近はバードレンジを設けて連続使 用を禁止していたのが, 船舶の減速運転の普及に伴って 常に経済的に最適な回転数を選択できるようバードレン ジ無しの要請がでる場合等である.

このような最近のねじり振動に関する状況の变化等に ついて以下に述べる。

\section{2. ねじり振動関連の状況}

最近のねじり振動に関する主な状況変化としては, バ ードレンジの廃止傾向や, 定速雨車装置の使用等があり, 又機関の高出力化や燃焼改善のための爆発圧力の上昇, 小数気筒機関の実用化等の傾向むねじり振動に影響して いる面がある・

2.1 バードレンジの廃止石油ショック以来各 方面で省エネルギ化が進んでいるが，船舶関係で最む簡 単で効果の上る省エネルギ対策は船舶の減速運転である. このような背景から天候・海象・航海距離等を総合的に 考慮して，最屯経済的な速度を常に維持できるように， バードレンジを設けなくて良い軸系が望まれて来た。し かしながら通常の機関ープロペラ直結の軸系では 1 節主 危険速度が使用回転範囲内に入って来る例が多く，その 附加応力は船級ルールの許容応力線を越える場合もかな り有る. 又たとえ越えていなくともプロペラ减衰が大き く効く 1 節振動では，プロペラ空転時等急速にプロペラ 减衰が失なわれることを考慮して，従来はバードレン ジを設ける場合が数多く見られた．したがって全回転範 囲を使用するにはプロペラ減衰に依存せずに 1 節振動の 附加応力を下げるか，1節主危険回転数を定格回転数の 上へ追い上げねばならない． 1 節振動数を上へ追い上げ るためには普通中間軸やプロペラ軸の径を太くする方法

* 原稿受付 昭和 61 年 10 月 31 日

**正会員 （株）新潟鉄工所（新潟県南魚沼郡六日町大字川 窪 1111)

Journal of the M.E.S.J., Vol. 22, No. 8
が有るが，このため中間軸の径が極端に太くなり，ロン グストロークの大形 2 サイクル機関等では, ルール上必 要とする軸の最小径の $1.5 \sim 2.0$ 倍程度の $\phi 700 \mathrm{~mm} \sim$ $\phi 1 \mathrm{~m}$ を越える中間軸まで検討されている.

他の方法はねじり振動ダンパを装着して，1節振動の 附加応力を下げ，許容応力以下にすることである．普通 ねじり振動ダンパはクランク軸フリー端に取付けられ, クランク軸と一体となって変動しながら回転している一 次側マスと，ほぼ一定回転している慣性輪と称する二次 側マスとが有り，その間に粘性減衰の働きのみを有する 流体の介在しているタイプのものと，ばね特性と減衰性 能を有する物体の介在しているタイプのあのとがある. 前者の代表例はシリコンダンパであり，後者の代表例は ゴムダンパや金属ばねを使用した各種のダンパであ る・1 節振動用ねじり振動ダンパは従来から用いられて いた 2 節振動（機関単体振動）用ダンパに比べて非常に 大きくなっている．これは主にクランク軸前半部分のみ が大きく振れ，はずみ車やプロペラはあまり振れないモ ードの 2 節振動と異り，慣性モーメントの大きなはずみ 車やプロペラも比較的大きく振れている 1 節振動の振幅. 附加応力を低减するためには，ダンパも大きな慣性モー メントを有する慣性輪が必要なためである．したがって 従来ならば 2 節振動用ダンパ選定に対し多少の安全を図 って大き目のダンパを装着するようなこと屯可能であっ たが，1節振動用ダンパは必要最小限を狙った設計が必 要で, 又振動上最適值を得るために減衰係数を自由に設 定できる構造の必要がある.なぜならばねじり振動ダン パは図 2 に示すように減衰が小さ過ぎても，又大き過ぎ

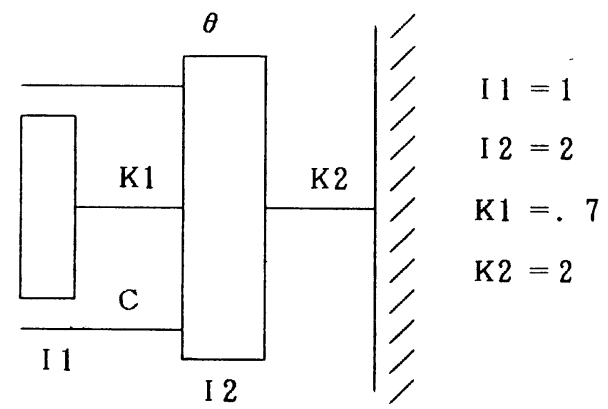

図 1 ダンパ付軸系 


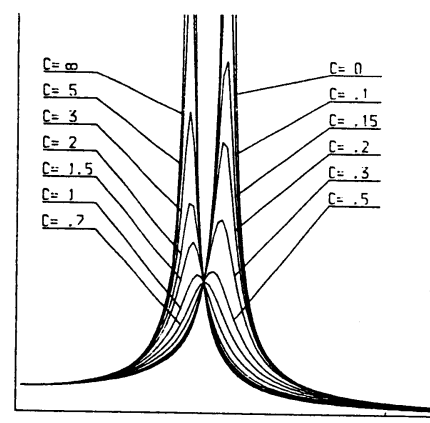

SILICON DAMPER

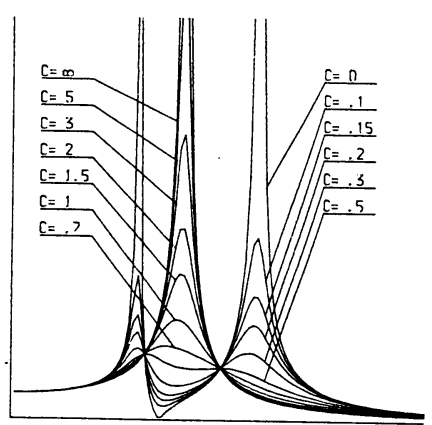

GEISLINGER DAMPER

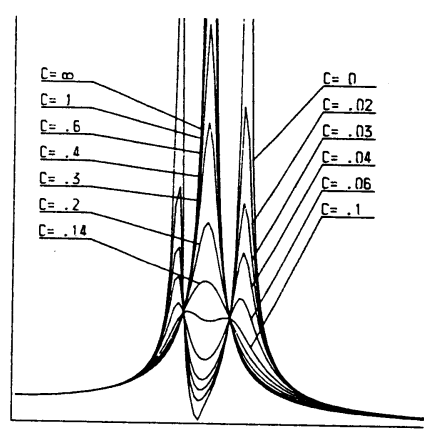

(SMALL SIZZE)

困2 ダンパ付軸系のねじり振動

て屯振幅が増大するので, 減衰係数には最適値が存在す るからである・比較的簡単に任意の減衰係数を設定でき るのはシリコンダンパと金属ばねを使用したガイスリン ガーダンパであり，1節振動用ダンパとして実績のある のはこの 2 種である. 図 3 , 図 4 にこれらのダンパの構 造を示す.困 2 の左のグラフはシリコンダンパを想定し ており, 図 1 に示す軸系のダンパばね常数 $\mathrm{K}_{1}=0$ の場 合であり, 図 2 の中央のグラフはガイスリンガーダンパ を想定しており，図 1 中の $K_{1}=0.5$ の場合である. 同 じ慣性モーメントのダンパでも, ガイスリンガーダンパ の方が振幅が約 1 / 2 になっている. そこでガイスリン ガーダンパの 2 次側マス慣性モーメントを図 1 に示す軸 系の $1 / 4$ に減小した結果が図 2 の右のグラフである. これであシリコンダンパの振幅と同等ないし多少小さ目 である。

ダンパを使用して 1 節振動の附加応力を低減すること でバードレンジを無くすよう計画するためには，振幅の 正確な把握が必要であり, 後述のように振幅計算の精度 向上が図られねばならない。

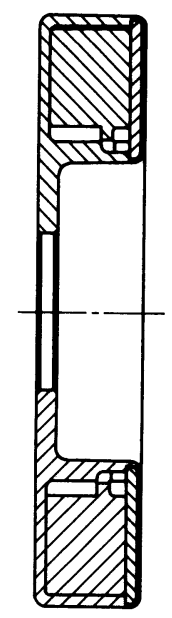

図 3 シリコンダンパ
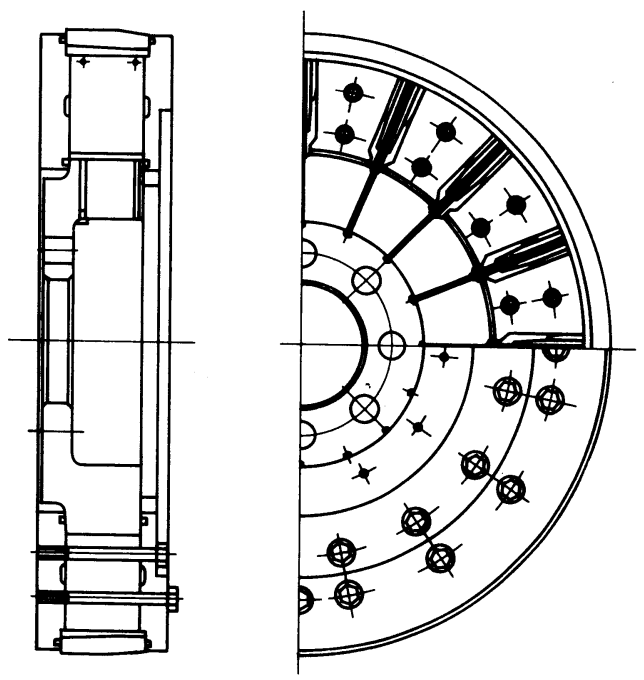

図 4 ガイスリンガーダンパ

2.2 定速歯車装置の使用石油ショック以来船 舶全体の燃料経済性が追求されており，その中で脚光を あびたのが主機発電装置である.これは小形の補機ディ 一ゼル機関よりあ，低質油燃焼が可能で然費の良い主機 により発電機を駆動すれば, 燃料経済が図れる上効率の 良い高負荷域での運転になる．そのため必要な船速を得 るために主機の回転数を変化させて屯発電機の回転数は 一定に保たれるように連続可変増速比の雬車増速機, す なわち定速菌車装置が用いられてきた.この装置は図 5 に示すように遊星雨車式増速機で，キャリヤが入力側に， サンギヤが出力側になっている. 通常インターナルギヤ は固定されているのだが, 定速柬車装置では可変容量形 の油圧ポンプ/モータにより回転することができるよう になっており，インターナルギヤがキャリヤと同方向に 回転すると増速比が減る方向で, 逆方向に回転すると増 速比は増える方向になる. 例えばインターナルギヤがキ ヤリヤと同方向同速度で回転すれば増速比は 1 . 0 にな ることは容易に理解できよう。 


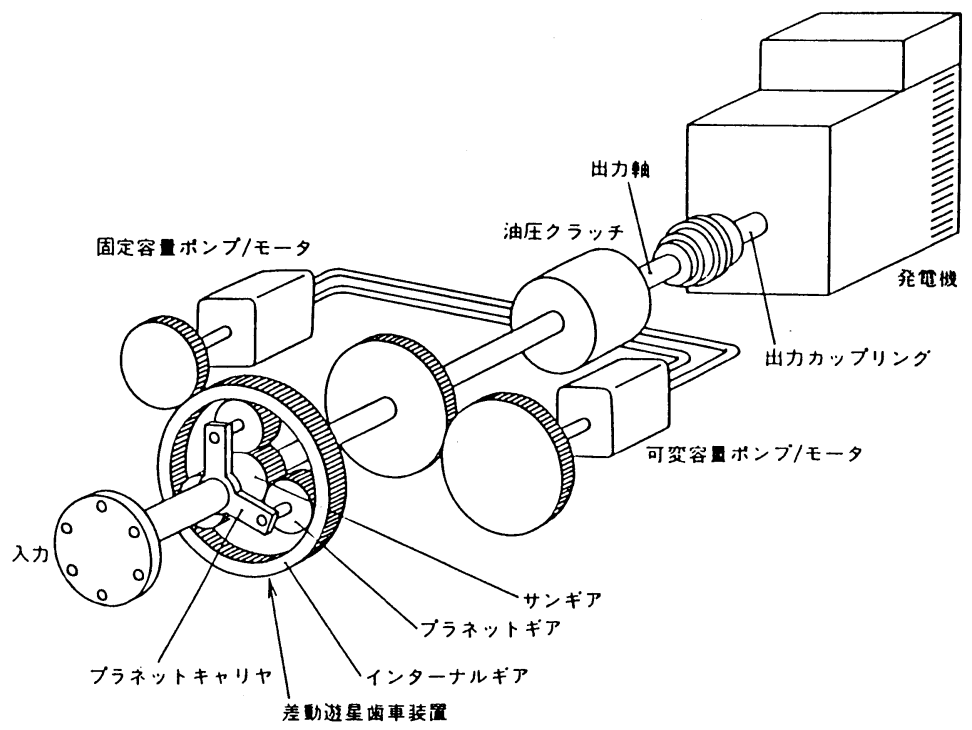

図 5 定速歯車装置

このような定速歯車装置を含む軸系のねじり振動をど う扱うかの定説はなく, 各社独自の解釈に基いてねじり 振動計算モデルを構築しているようであるが, 類似のも のをまとめると, 各時点での増速比に伴って本装置の出 力側の慣性モーメントとねじりばね常数が増速比の 2 乗 に比例して変化すると考えて計算モデル化しているグル ープと，キャリヤからサンギヤとインターナルギヤとに 枝分れしており，現実の増速比とは関係なく常に一定の 計算モデルと考えているグループに別けられる。筆者は 後者のうちキャリヤの振幅を両枝の等価慣性モーメント に反比例する比率で二分した振幅がサンギヤとインター ナルギヤに働くとの計算モデルが実際に近いと考える. いずれにしても手計算を行うのは困難でコンピュータ化 する必要があり, 又従来からねじり振動計算をコンピュ 一タ化していても, 何らかの計算機能を附加しなければ このシステムの解析はできないので, 現状では必要に迫 られる部門すなわちギヤメーカが独自の解釈に基いて開 発したプログラムのみによって解析可能であるというの が実態である。

2.3 爆発圧力の上昇機関出力率の上昇に伴う シリンダ内圧力の上昇や, 熱効率改善に伴うシリンダ内 最高圧力の上昇は，ねじり振動を起す原因となるトルク ハーモニックスの増大に慗がり, 従来どおりの計算によ る振幅と実測振幅との間に大きな差異が生じてきた・前 記のように振幅計算の精度が要求される一方でこのよう な計算誤差が増大して行くようでは意味がないので, ト ルクハーモニックスの精度向上を図らねばならない. 幸 い機関の低燃費化の研究が精力的に行われたので, 燃焼 解析の手段としてシリンダ内圧力計測の技術が進歩し, 精度良い指王線困のデータ収集む進んできていた。この
ため各機関メーカやワールドワイドの機関ライセンサー 等で代表機種について指王線図からトルクハーモニック スを求めており，これら代表機種のトルクハーモニック スの精度は飛躍的に向上した. 従来のトルクハーモニッ クスと新しいトルクハーモニックスでねじり振動計算を 行った結果を図 6 に比較表示する.図で判るように従来 どおりの計算では許容応力以下であるが, 新しい計算で は許容応力を越えている。このままで製造した場合には， おそらく実測值も許容応力を越えたものと思われる。な 扣これら代表機種でなく相似設計機関や類似機関に対し てもこの新たに求められたトルクハーモニックスを適用 すれば従来よりかなり改善されるが，でき得れば代表 1 機種のデータからトルクハーモニックスを調整するので なく，数機種の指圧線図データから最小自乗法により平 均的なトルクハーモニックスを調整することが望ましい その場合には例えば 2 サイクル機関なら $\mathrm{S} / \mathrm{D}$ 比 2 前後 のあのと, 3 前後の超ロングストローク形, 定格出力時 平均有効圧 $2 \sim 3$ グループ等, 又 4 サイクル機関なら高 速・中速・低速の別, 定格出力時平均有効王 $2 \sim 3$ グル ープ等の数グループに分けてそれぞれトルクハーモニッ クスを調整しておけば良いと思われる。

2.4 燃焼のばらつき 機関の高出力率化や, 最 高爆発圧力の上昇は前述のようなトルクハーモニックス 全体のレベルの上昇だけでなく，主として低負荷運転時 における各気筒ごとの燃焼のばらつき幅も大きくしてい る。したがって各気筒ごとのトルク変動成分がたがいに 打消し合って全体の起振力は小さくなるため, 従来はま ったく考慮をはらっていなかった 1 節副次の成分に対し ても，気筒間に燃焼のばらつきがあると思いがけない共 振が現われる場合がある。このような場合を想定して各 

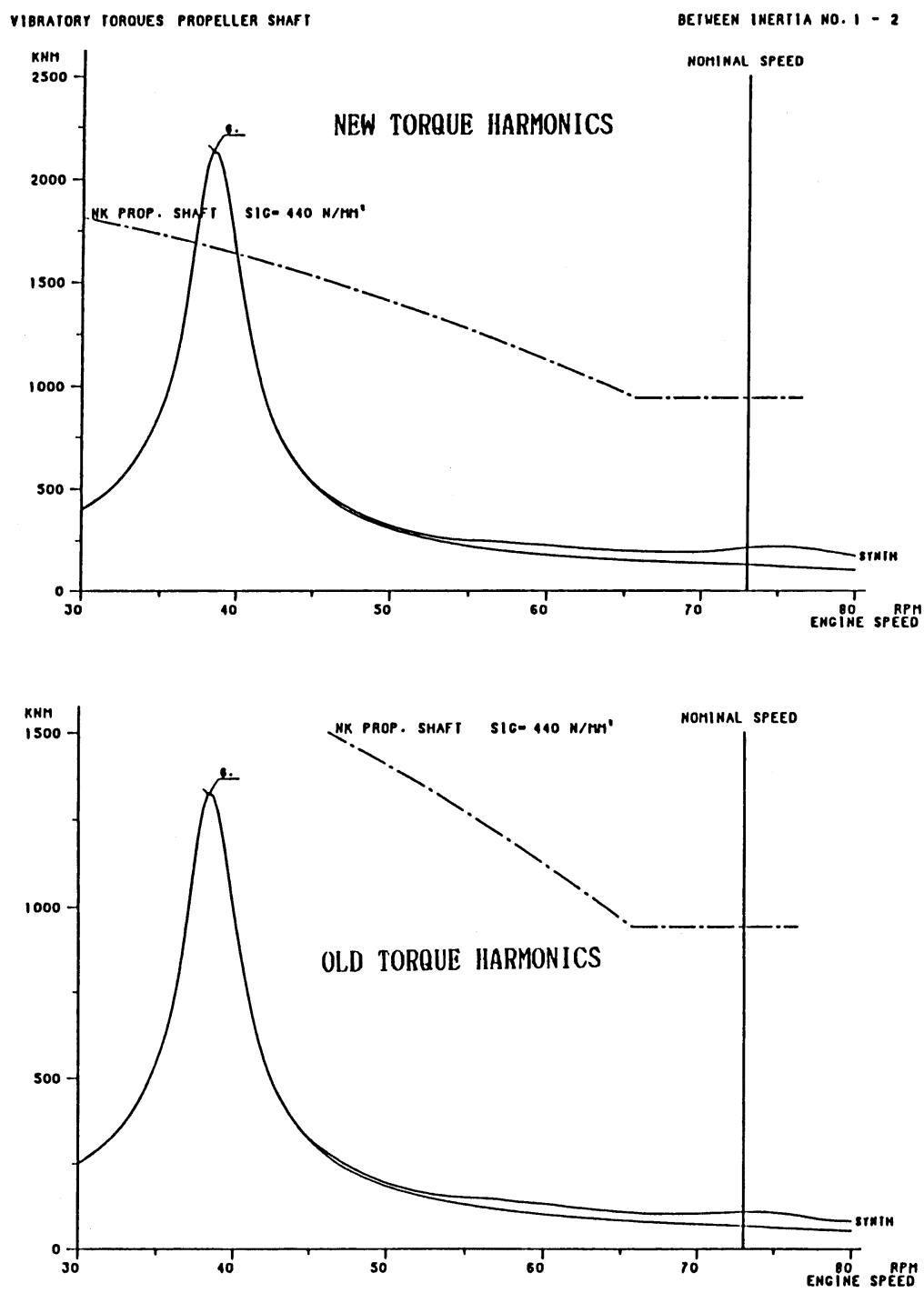

図 6 トルクハーモニックスの相異による比較

国の船級協会の間では，ねじり振動計算書の作製に際し て通常の計算の他に, 一気筒ミス着火の条件の計算を参 考用に提出するよう求める所が次第に増えてきている。 しかしながらミス着火の計算結果で許容応力値をオーバ 一していたとしてあ, バードレンジを設定することなく, 単なる参考資料としているのは， ミ着火運転による軸 の切損事故を心配していると言うよりは，かなりの頻度 で起り得る燃焼ばらつきのある運転状態で, 各気筒間の アンバランスによってどのような共振現象が現われるか をチェックするのが目的であり，1気筒ミス着火の計算 を行うのは各気筒相互間のバランスをくずす手段として いるのに過ぎない.

正常燃焼時には現われず，ミス着火ないし燃焼ばらつ きにより現われるねじり振動共振が原因となって推進軸
系に損傷事故を起すようなことはほとんど無いが，前述 した主機発電装置における定速菌車装置や弾性継手・軸 等の動力伝達機構が損傷事故を起すような例は有り得る。 燃焼ばらつきによる共振は実際にはそれほど大きな振動 ではなく, 推進軸系の伝達トルクに対し振動附加トルク は比較的小さいのであまり問題とはならないが，一般的 に推進軸系に比べ伝達トルクが小さく，細い軸で構成さ れている主機発電装置では, 伝達トルクに対する振動附 加トルクの割合が比較的大きく，場合によっては損賃に 至ることあ充分考えられることである。このような燃焼 のばらつきによって生じるねじり振動は 4 サイクル機関 では 0.5 次ごとに, 又 2 サイクル機関では 1 次ごとに現 われるので, 自然振動数の調整で危険な振動を回避する ことは難かしく，そのため発電機駆動軸系に大きな减衰 
を与えて振幅を下げるようにしなければならない。この 発電機駆動軸系に遊星歯車の衝撃緩和を兼枋た高弾性・ 高減衰の弾性継手を採用することは, 実用的で効果のあ る対策である。

\section{5 少数気筒機関 2サイクル少数気筒機関は} 同一出力で多数気筒機関の場合よりも部品点数が少なく メンテナンスが容易になることと，燃料消費率とプロペ ラ効率が良くなり省エネルギ効果があるため, 最近主機 に使用される例が多くなっている。少数気筒であっても ねじり振動の解析が特殊になるわけではなく，従来とま つたく同じ手法を用いて解析すれば良いのであるが，こ の場で少数気筒機関を取上げたのは，例えば 5 気筒機関 の場合には主危険振動が 5 次であり，従来に比べ低次な のでトルクハーモニックスが大きく，その分だけ大きな 振動が発生することと, 通常の軸系では常用回転附近に 共振が発生するケースが多いため，何らかの対策が必要 との理由からである。この対策と前述のバードレンジ無 しの対策を兼ねて, 中間軸径・プロペラ軸径を太くし共 振回転数を定格回転の上に追い上げる方法や，1節振動 用ダンパを装着する方法等があり, 省エネルギと減速運 転と言う市場ニーズにマッチしたシステムが構築され る.

なお最近生産されている少数気筒機関はすべて超ロン グストロークの高出力率機関であり, 最新のトルクハー モニックスを使用する必要がある。又燃焼のばらつきに ついては少数気筒機関の方がより大きな影響が出るので, 特に主機発電装置を装備した少数気筒機関については注 意が必要である、今まで述べてきた最近のねじり振動の 各種傾向は，このように少数気筒機関において最屯顕著 に表われていると言って良い。

\section{3. ねじり振動解析の傾向}

3.1 従来の解析手法 ねじり振動の解析は軸系 を多質点のばねーマス系の振動モデルに置換えているの が一般的である。従来はこのモデルについてホルッア表 によって最低次の 1 節振動から，順次必要節数の振動ま で, 自然振動数と振動モードを計算し, 次にこの各節に 対して機関回転の各次数成分に共振する点の振幅・附加 応力を経験的な式によって求めていた。この経験式には 二つの系統があり，その一つはエネルギ法で, 共振点に おけるモードに対して強制エネルギと減衰エネルギをそ れぞれ求め, 両者が一致する時の振幅を求める方法であ り，減衰エネルギを求める計算式に各社それぞれ工夫を している. 又他の一つは共振倍率法で, 同じく共振点に おけるモードに対して平衡振幅を最初に求め, 次に減衰 を考慮して共振倍率を求めて, 両者の積を共振点におけ る振幅とする方法で, 同じく共振倍率を求める計算式に 各社の経験を加味したノウハウを導入している。

いずれの方式でも共振点における振動モードを基礎と して計算しているので, 共振点からはなれた位置で, 振
動モードがくずれている回転域における振幅・附加応力 の計算結果にはかなりの誤差が含まれていることを覚悟 しなければならない. 又共振点附近においても軸系各部 の正確な減衰能の把握がなされなければ，精度の良い振 幅・附加応力の計算をすることができないのは無論であ るが，たとえ個々の減衰を正確に把握できたとしても， 特に共振倍率法の場合には各モードごとに全体の減衰に 対する各部の減衰の割合を出し, 精度の良い共振倍率を 推定するのは困難である。したがって主機関一プロペラ 直結のような単純で過去多くの類似軸系の実績のある軸 系については, 経験をふまえ比較的精度の良い共振倍率 を推定することあ可能であり，計算が簡単であることか ら従来好んで用いられていた。しかしながら主機発電の 軸系や, ダンパ付軸系, 又古い話になるが中速機関の減 速逆転機付の軸系の初期のころ等，今まで実績がなく未 知な振動モードに対しては, 共振倍率の推定にはかなり の誤差が含まれる可能性がある。それでも従来あまり支 障なかったのは, ねじり振動計算書は参考資料であり， 実測により必要に応じてバードレンジを設けるのが本則 で，類似軸系の実績があり計算結果に信頼性のある場合 のみ実測を省略することができるとの扱いをしているか らである。

3.2 新しい解析手法 バードレンジ無しの軸系 を設計する場合には，計算によって精度良い振幅・附加 応力の推定をすることが不可欠である。その方策は，

（1）強制トルクを正しく把握する.

(2) 減衰能を隣接するマス相互間の相対减衰と, 各マ スの絶対減衰に分離して精度良く把握する。

（3）共振をはずれた点の振幅も理論的に解析する。

（4）各振動の位相も把握し，各次数の加算も行えるよ うにする。

等が考えられる。強制トルクを正しく把握するには，前 述のように各機種ごとないし類似機種グループごとに指 圧線図の実測值からトルクハーモニックスを調整し，そ れを計算に使用すれば良い。

最近機関性能の改善試験の手段として指圧線図を正確 に計測する努力が行われ，燃焼室面に直接冉力ピックア ップを取り付けて気柱振動によるノイズを排除すること の重要性が認識され，ピックアップ取付用の追加工を行 った圧力計測専用のシリンダヘッドを準備したり，数十 から数百サイクル分を平均化して一時的な異常燃焼の影 響を排除した計測が行われることにより，高次のトルク ハーモニックスまでかなり正確に求めることは比較的容 易である。

減衰能については軸のねじれによる内部摩擦減衰や， 弾性継手・ダン八゚等で与えられるマス相互間の相対減衰 と，軸と軸受，ピストンとライナ間のように油膜を介し てスライドしている部分や, プロペラ, 発電機ファン等 のように流体中を振動するために生じる絶対減衰とに分 離して把握すべきである。そうすれば軸の相対ねじれは 
あまり大きくなく，機関シリンダ部分や，プロペラ部分 が大きく振れている 1 節振動のような振動モードで支配 的な絶対減衰，相対ねじれが比較的大きくなる高節の振 動モードに大きく影響する相対減衰等モードによる各減 衰の寄与率を考慮できる。なおピストンとライナ間等の 減衰は個々のばらつき屯大きく，又摺合せ運転前とリン グになじみのついた摺合せ運転後とではねじり振動実測 振幅値に明らかな差がある例ああり, 正確な数值を把握す るのは困難であるが，より精度良く振幅を求めたいバー ドレンジ無しのタンパ付軸系では，ダンパの減衰が支配 的で，これを正確に把握できればその他の減衰は多少精 度が悪くともかなり良い結果を得ることができる。

次に共振点をはずれた点の振幅計算と, 位相を考慮し た各次数の振幅・附加応力の加算については, 従来のホ ルツァ表を用いたモード解析法から周波数応答法ないし 時刻歴解析法への転換が必要である。時刻歴解析をする には各回転・各負荷ごとにトルクカーブを求めることが 必要で，すべてを計測によりあらかじめ求めておくこと は不可能なので, トルクハーモニックスから合成して求 めることになるが, これでは各次数ごとに周波数応答法 により求めて結果を合成しても同じであり，又この方が 各次数の共振位置や成分も求まるので，一般には以下に 示すような周波数応答法が多く用いられている。

最も単純な周波数応答法による計算は主次数（2サイ クル機関ではシリンダ数の整数倍, 4 サイクル機関では シリンダ数の $1 / 2$ の整数倍の次数) に対する減衰無し の軸系モデルについての計算で，位相を考慮する必要が ないので，ホルツァ表を少し改良すれば計算することが できる．すなわち表 1 に示すように従来のホルツァ表に 強制トルクの列を追加して, 振幅の初期值を未知数とす ることによって, 表の各闌は未知数 $x$ の一次式になって いるので, 以下の手順で未知数 $x$ （すなわち前端振幅） を求めることができる。

（1）従来と同じく振幅の初期值を 1.0 とし, 強制トルク を考慮せずに表計算し，余㮃トルク $g_{n}$ を求める.

（2）振幅の初期值を０とし各強制トルクを加えながら表
計算を進め, 余剰トルク $G_{n}$ を求める

（3）表 1 の余剰トルク $[g x+G]_{n}$ は 0 であるので, $g_{n} x+G_{n}=0 \rightarrow x=-G_{n} / g_{n}$

により末知数 $x$ を求める.

（4）求めた $x$ を代入し各欄の数值を求める.

但し, $\mathrm{A}$ は角振動数 $\omega$ の 2 乗

B列は各慣性モーメント

C 列は単位角度当りの各慣性トルク

$\mathrm{D}$ 列は各振幅

E列は各慣性トルク

$\mathrm{F}$ 列は各強制トルク

$\mathrm{G}$ 列は各振動トルク

$\mathrm{H}$ 列は各ばね常数の逆数

$\mathrm{J}$ 列は各相対振幅

なお主次数以外の副次数については，強制トルク相互 間に位相差があるため位相を考慮した計算が必要になる が，上記の手法を少し工夫すれば解決できる。すなわち 各強制トルク $F_{i}$ の基準角度に対する位相をそれぞれ $\varphi_{i}$ とすると上記 $F_{i}$ を成分に分解し, $F_{i} \sin \varphi_{i}=F_{i s}$, $F_{i} \cos \varphi_{i}=F_{i c}$ とし, 又未知数 $x$ む $x \sin \varphi_{x}=x_{s}$, $x \cos \varphi_{x}=x_{c}$ と置くことによって $\sin$ 項 $\cdot \cos$ 項そ れぞれ別個に上記手法で $\theta_{s} ， \theta_{c}$ を求めてその後合成す れば良い。

同じく位相を考慮した計算でも減衰項を考慮する場合 はそれほど単純ではない。なぜならば sin 項の表で現わ れた減衰トルクは $\cos$ 項の表へ受渡し， $\cos$ 項の表で現 われた減衰トルクは $\sin$ 項の表へ受渡さねばならず, 両 者の表計算は同時平行して行わねばならないからである.

したがってこの場合には伝達マトリックス法によって まとめる方が理解が容易である。図 7 に全体の軸系のう ちマス $i$ 附近のモデルを示す. 解りやすいようにマス $i$ のフロントサイドとリヤサイドの振幅 $\theta$ と振動トルク $\tau$ を定義しそれぞれ添字 $f, r$ を付けると各関係式は，

$$
\begin{aligned}
& \theta_{i f}=\theta_{i r} \\
& I_{i} \dot{\theta}_{i f}+D_{i} \dot{\theta}_{i f}+T_{i}+\tau_{i f}=\tau_{i r} \\
& \tau_{i r}=\tau_{(i+1) f}
\end{aligned}
$$

\begin{tabular}{|c|c|c|c|c|c|c|c|c|}
\hline $\mathrm{i}$ & $\begin{array}{c}\text { B } \\
(\mathrm{I})\end{array}$ & $\begin{array}{c}C \\
B * A\end{array}$ & $\begin{array}{c}D \\
D-J\end{array}$ & $\begin{array}{c}\mathrm{l} \\
C * \mathrm{D}\end{array}$ & $\begin{array}{c}F \\
(1)\end{array}$ & $\begin{array}{c}G \\
E+F+G\end{array}$ & $\begin{array}{c}H \\
\text { (I) }\end{array}$ & $\begin{array}{c}J \\
G * \|\end{array}$ \\
\hline 1 & [B] 1 & {$[\mathrm{C}] 1$} & $x$ & $e x$ & {$[F] 1$} & {$[g x+G] 1$} & [II ] 1 & {$[j x+J] 1$} \\
\hline 2 & {$[B] 2$} & {$[\mathrm{C},]_{2}$} & {$[d x+D] 2$} & {$[e x+E] 2$} & {$[F] 2$} & {$[g x+G] 2$} & [II $] 2$ & {$[j x+J] 2$} \\
\hline • & - & • & - & $\cdot$ & $\cdot$ & $\cdot$ & - & - \\
\hline - & ; & - & - & - & - & - & - & . \\
\hline i & {$[B] \mathrm{i}$} & {$[\mathrm{C}] \mathrm{i}$} & {$[d x+D] i$} & {$[e x+E] i$} & {$[\mathrm{~F}] \mathrm{i}$} & {$[g x+G] i$} & {$[11] \mathrm{i}$} & {$[j x+J] i$} \\
\hline • & . & . & - & . & . & $\cdot$ & $\cdot$ & $\cdot$ \\
\hline - & . & • & . & . & & $\cdot$ & • & • \\
\hline$n$ & {$[B] n$} & {$[\mathrm{C}] \mathrm{n}$} & {$[d x+D] n$} & {$[e x+E] n$} & {$[i] n$} & {$[g x+G] n$} & & \\
\hline
\end{tabular}

表 1 周波数応答法によるホルツヶ表

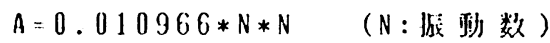

（I）データINPUTを永す。 
$\left.K_{i}\left(\theta_{i r}-\theta_{(i+1) f}\right)+C_{i} \dot{\theta}_{i r}-\dot{\theta}_{(i+1) f}\right)=\tau_{i r}$ となる。上の 2 式から次のマトリックス式が得られる. $\left\{\begin{array}{c}\theta i r s \\ \theta i r c \\ \tau i r s s \\ \tau i r c \\ 1\end{array}\right\}=\left[\begin{array}{ccccc}1 & 0 & 0 & 0 & 0 \\ 0 & 1 & 0 & 0 & 0 \\ -I i \omega^{2} & -D_{i} \omega & 1 & 0 & T i s \\ D i \omega & -I i \omega^{2} & 0 & 1 & T i c \\ 0 & 0 & 0 & 0 & 0\end{array}\right\} \cdot\left\{\begin{array}{c}\theta i f_{s} \\ \theta i f_{c} \\ \tau i f_{s} \\ \tau i f_{c} \\ 1\end{array}\right\}$

本式はマスiを挟んだ前後の伝達マトリックス式である。 第 4 式を変形すると

$$
\left\{\begin{array}{l}
K_{i} \theta_{(i+1)} f_{c}-C_{i} \omega \theta_{(i+1) f_{c}}=K i \theta i r s-C_{i} \omega \theta_{i r c}-\tau i r s \\
C_{i} \omega \theta_{(i+1)} f_{s}+K_{i} \theta_{(i+1) f_{c}}=C_{i} \omega \theta i r s+K_{i} \theta_{i r c}-\tau i r c
\end{array}\right.
$$

となる。 $\theta_{(i+1) f_{c}}, \theta_{(i+1) f_{c}}$ についての解を求め, 上 式の第 3 式と合せて次のマトリックス式が得られる.

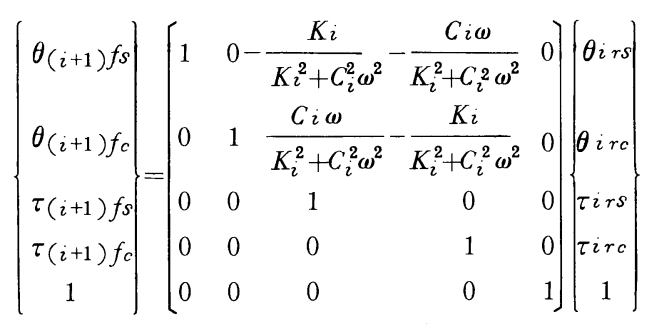

本式は隣接するマス間の軸の伝達マトリックス式である。 $n$ 質点系モデルの場合， $n$ 個のマス前後の伝達マトリッ クスと $n-1$ 個の軸の伝達マトリックスが導き出される ので, これら $2 n-1$ 個のマトリックスすべての積のマ トリックスを $[A]$ とすると

$\left\{\theta_{n r s}, \theta_{n r c}, \tau_{n r s}, \tau_{n r c}, 1\right\}^{T}=[A]\left\{\theta_{1 f_{s}}, \theta_{1 f_{c}}, \tau_{1 f_{s},}\right.$ $\left.\tau_{1 f_{c}}, 1\right\}^{T}$ となり, $\tau_{n r}=\tau_{1 f}=0$ であるから，

$\left\{\theta_{n r s}, \theta_{n r c}, 0,0,1\right\}^{T}=[A]\left\{\theta_{1 f_{s},}, \theta_{1 f_{c}}, 0,0,1\right\}^{T}$

で， 4 個の式と 4 個の未知数なので解析が可能である. $\theta_{1} f$ が求まれば先に得られた各伝達マトリックスによっ て, 各位置の振幅・振動トルクを順次求めることができ る. 以上が一つの周波数 $\omega$ につての応答であるが， $\omega$ を順次変えて上記操作を繰返せば周波数応答曲線が求ま る。本方式は非共振域等の計算精度の良さから, 特にダ ンパーメーカや継手メーカの間で普及し, 計算サービス を行う例が増加しているが, エンジンメーカの間ではい まだ一般的ではない。

先の定速菊車装置のメーカの場合も含めて, 最近計算 サービスを始めた所の方が, 計算解析法は進んでいるよ うである。

\section{4. ねじり振動実測の傾向}

ねじり振動の実測はねじり振動計による振幅の測定が
一般的で，トルクあるいはねじり応力を直接計測するこ とは特別な目的以外はほとんど行われていない. ねじり

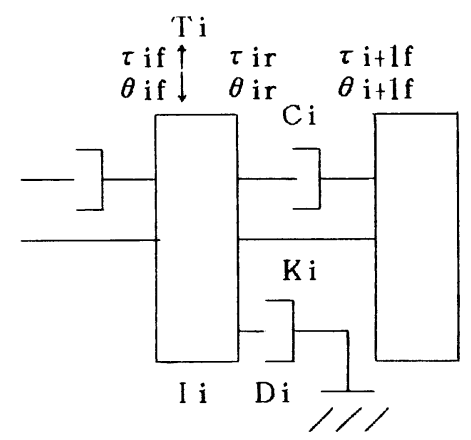

図 7 ねじり振動軸系の一部

振動計は従来より機械式のガイゲルねじり振動計が使わ れ，現在でも最も多く使われている。ガイゲルねじり振 動計には標準型之高速型があり，2 サイクル低速機関で は標準型ガイゲルねじり振動計で充分であるが，4サイクル 中・高速機関では高速型ガイゲルねじり振動計でも振動数に よっては測定精度に問題が出る場合あある。したがって 振幅を電気信号として取出し，F F T 解析を行うような システムも開発され，中・高速ディーゼル機関向に利用 され出してはいるが, シートライアル時その場で解析す るには装置も大がかりであり, 又操作あ複雑であるし， シートライアル時データ取込みのみを行って解析は後 に行うような方式では，検査官立会の下で結論を出すこ とができないので，使用は限られたものになっている． 特に中・高速機関メーカの場合, 据付指導で造船所へ出 向いた人がそのままシートライアル立会する例が多いの で, 一人でハンドキャリ可能で, 操作の簡単な電気式ね じり振動計の出現が望まれる。

\section{5. ま と め}

ねじり振動に関する事項で, 最近の特徵ある傾向につ いて筆者の経験している範井で述べてみた．文中で屯述 べているように，これらの傾向がすべて一般的に行き渡 っているわけではないが, 各方面で新しい試みが行われ ていることはご理解いただけたと思われる。しかしなが らこれら新しい試みは, 最近造船界への進出著しい韓国 と，斜陽化が言われて久しい欧州各国において受入れら れており, 我が国では高出力化, 低燃費化, 小数気筒機 関の採用等に対しては積極的であるが，ねじり振動の面 に関しては保守的であるように思われる。 